\title{
Improved method for triacylglycerol-derived fatty acid profiling by various non-lethal and lethal sampling techniques in Atlantic salmon
}

\author{
Rolf Erik Olsen ${ }^{1, *}$, Geir Lasse Taranger ${ }^{2}$, Terje Svåsand ${ }^{2}$, Ove Tommy Skilbrei ${ }^{2}$ \\ ${ }^{1}$ Institute of Marine Research, Matre Research Station, 5984 Matredal, Norway \\ ${ }^{2}$ Institute of Marine Research, PO Box 1870 Nordnes, 5817 Bergen, Norway
}

\begin{abstract}
The current paper compares the use of adipose fin and muscle biopsies as non-lethal sampling procedures, and the suitability of triacylglycerol (TAG) versus total lipid (TOT) fatty acid composition (fatty acid methyl esters, FAME) to estimate dietary history in farmed and wild maturing Atlantic salmon Salmo salar. TAG FAME gives best resemblance to dietary history. Fatty acid composition differs between tissues, and sample series should preferably be from 1 tissue only. TOT FAME supplies informative data on dietary history in fatty tissues, but differs from TAG FAME when total lipid levels are low. The reason is a larger contribution of phospholipid FAME. In wild maturing salmon, lipid content in adipose fin and muscle is low. TAG provides good data on dietary history, while TOT is less informative. Escapees are well identified analysing 18:2n-6 and 18:3n-3 fatty acids, which are high in commercial feed. For estimating a wider range of dietary history after escape (switch to wild prey), or feed preferences in wild fish, other fatty acids have to be taken into account. This requires the use of multivariate methods, like principal component analysis. Adipose fin and muscle biopsies are good alternatives for non-lethal sampling using the TAG method. The minimum amounts of samples to be used are proposed to be 0.5 to $1 \mathrm{~g}$ of adipose fin and 60 to $100 \mathrm{mg}$ of muscle. The method of storage (liquid nitrogen/dry ice) does not affect fatty acid compositions. Other tissues can also be used for fatty acid profiling. Snout is a good alternative, being lipid-rich even in wild fish with low muscle lipid.
\end{abstract}

KEY WORDS: Fatty acid composition · Fatty acid profiling · Adipose fin · Triacylglycerol $\cdot$ Muscle · Snout $\cdot$ Escaped farmed salmon

\section{INTRODUCTION}

With the rapid expansion in farming of Atlantic salmon Salmo salar over the past $50 \mathrm{yr}$, escapes from cages have become a serious problem, both for the fish-farming industry and for the conservation of wild stocks. The official figures of salmon escaping from fish farms in Norway show a variable trend ranging from 38000 to 921000 during the period from 2001 to 2012 (Directorate of Fisheries; www.fiskeridir.no). However, these figures are considered lower than the actual number of fish escaping (Baarøy et al.

*Email: rolf.erik.olsen@imr.no
2004, Skilbrei \& Wennevik 2006). Escapees may spread diseases and parasites (Heuch \& Mo 2001, Skilbrei et al. 2010). Some may also enter rivers to spawn (Sægrov et al. 1997). Genetic changes have been demonstrated in wild salmon populations as a result of interbreeding between farmed escaped salmon and wild conspecifics (Crozier 1993, Clifford et al. 1998, Glover et al. 2013).

Fish may escape during all stages of the production cycle, from hatcheries in freshwater and from netpens in seawater (Jensen et al. 2010). The spawning behaviour of salmon that escape at an early life stage

() The authors 2013. Open Access under Creative Commons by Attribution Licence. Use, distribution and reproduction are unrestricted. Authors and original publication must be credited. 
is relatively similar to that of wild fish, while being very different from salmon escaping as adults (Fleming et al. 1997). Fish that escape from sea net-pens during their first spring/summer migrate to the open ocean and return to spawn after 1 to $3 \mathrm{yr}$ (Skilbrei $2010 a, b)$. The time of escape therefore influences the risk of introgression of escaped cultured with wild salmon populations.

Knowledge about the escape history of salmon in rivers is important for risk assessments and also to develop efficient strategies to reduce the impact of escapements. Molecular genetic methods have been successfully implemented to identify the farm of origin for farmed Atlantic salmon captured shortly after their escape (Glover et al. 2008, Glover 2010). Furthermore, such methods have been adapted to assist the identification of farmed and wild salmon in the wild (Karlsson et al. 2011) and to reveal the mixture of escapees from multiple farms in the same region (Zhang et al. 2013). However, molecular genetic markers are not able to answer other questions linked to escapees, e.g. how long the escapees have been in the wild and if they have started to feed on wild prey. In order to address these and other ecological issues, other types of markers are required.

One such approach is the analysis of fatty acid profiles. Over the past decade, there has been a general switch towards higher inclusions of terrestrial type feed ingredients, including vegetable oils, in Atlantic salmon farming. There is also increasing interest in other terrestrial lipid sources such as poultry fat. The fatty acid profiles of these diets will differ significantly from the normal diet of wild Atlantic salmon in the marine environment. For example, vegetable lipids used in current salmon feeds are low in the typical marine polyunsaturated fatty acids (PUFA) 20:5n-3 and 22:6n-3 and high in shorter chain PUFAs like 18:2n-6 and 18:3n-3. There are also highly variable amounts of fatty acids like 18:1n-9 and 16:0, depending on type of oils used. As tissue fatty acid compositions in fish are, to a large extent, governed by the content of the diet (Henderson \& Tocher 1987 , Bell et al. 2001, Olsen et al. 2003, 2004, Torstensen et al. 2005), quantifying tissue lipids can enable the identification of escaped fish and give good estimates of feeding history and how long they have been eating natural prey after their escape.

Fatty acid profiling methods are already in use and have been used, e.g., to distinguish farmed from wild salmon (Molkentin et al. 2007, Axelson et al. 2009, Megdal et al. 2009) and the feeding patterns of horse mackerel Trachurus mediterraneus around sea cages (Fernandez-Jover et al. 2007). The application of the method varies between studies, which may affect interpretation of the data. Most commonly, authors analyse the total lipid (TOT) fatty acid compositions. However, such analysis includes both membrane lipids (phospholipids, PL) and depot lipids (triacylglycerols, TAG), whereby the relative contribution ranges from mostly $\mathrm{PL}$ in very lean fish to mostly TAG in very fat fish. The challenge in using TOT analysis is that the metabolic pathways of synthesis differ significantly between the 2 lipid classes. PL synthesis is under strict metabolic control (Henderson \& Tocher 1987, Olsen et al. 1991). In wild fish PL fatty acids are dominated by PUFAs (generally $>50 \%$, e.g. eicosapentaenoic acid [EPA] and docosahexaenoic acid [DHA]) in addition to 16:0, 18:0 and 18:1n-9. Other monoenes and PUFAs are generally very low. Changing diets has a limited effect on phospholipid fatty acid composition (Olsen et al. 2003). The fatty acid composition of depot TAG, on the other hand, mirrors the diet (Henderson \& Tocher 1987, Olsen et al. 1991, Corraze \& Kaushik 1999). Consequently, in lean tissues, applying total fatty acid analysis causes the PL fatty acids to dominate profiles, and does not give a good estimate of dietary history. In fatty tissues on the other hand, TAG contributes $>80 \%$ of the fatty acids and may thus give a good estimate of dietary history. However, lipid content in tissues may vary considerably, particularly in maturing Atlantic salmon that are anorectic before spawning and also invest considerable energy into gonad maturation (Aksnes et al. 1986, Kadri et al. 1996). Analysing TAG only may, in these cases, be advisory, and recent studies have shown a very good correlation between dietary fatty acids and muscle TAG composition in Atlantic salmon during simulated escapes from net-pens (Olsen \& Skilbrei 2010).

The tissues available for study may also vary depending on availability. In some cases, fish are killed, and it is possible to sample ample amounts of the desired tissue for analysis. For example, salmon may be tagged with a coded wire tag in the snout in release experiments and marking programmes (Hand et al. 2010), and heads or snouts of fish are collected from the salmon fishery for tag identification. Furthermore, there is also an increased demand in fish surveys for fish to be kept alive and returned quickly to the river after the sample has been taken. Non-lethal sampling is essential in these cases. Examples of such sampling targets include scales (Grahl-Nielsen \& Glover 2010), adipose fin, mucus, or muscle-biopsies. To ensure minimum damage to the fish, sample volumes need to be as small as possible. To address these questions, the current paper aims to (1) compare the ability of 
tissue TOT and TAG fatty acid profiles to describe diet history and (2) explore the suitability of adipose fin and small muscle biopsies as candidates for fatty acid profiling in maturing Atlantic salmon.

\section{MATERIALS AND METHODS}

\section{Sampling 1-Farmed salmon}

Farmed Atlantic salmon Salmo salar (1.5 kg average body weight) in $5 \times 5 \mathrm{~m}$ sea cages were fed a standard commercial diet (Skretting No. 9) until achieving a weight of $6.6 \pm 0.4 \mathrm{~kg}$, at approximately $83.9 \pm 2.2 \mathrm{~cm}$ fork length, mean $\pm \mathrm{SEM}, \mathrm{n}=15)$. The samples were collected in November during the spawning season (sexually mature fish), as this would be comparable to newly escaped salmon entering rivers for spawning. The fish were collected from the net-pen at sea and killed by percussion. Biopsy samples were immediately collected on the back side, posterior to the dorsal fin, using Osteo-RAM biopsy needles $(7 \mathrm{G} \times 100 \mathrm{~mm}$; RI.MOS s.r.l). The samples were then released into cryo-tubes and snap-frozen in liquid nitrogen, or put on dry ice. Control muscle samples were directly cut from the same fish and flash-frozen in liquid nitrogen. All samples were then stored at $-80^{\circ} \mathrm{C}$ prior to analysis. The biopsy samples were in the range from 40 to $100 \mathrm{mg}$, muscle samples were in the range from 400 to $900 \mathrm{mg}$, and adipose fin samples ranged from 300 to $600 \mathrm{mg}$. As an initial screening test, we chose 1 fish by random and analysed TAG samples from skin mucus, peritoneal adipose tissue, roe, tongue, muscle, liver and adipose fin.

The samples were then used for (1) comparing the fatty acid profiles of TOT and TAG of muscle and adipose fin and (2) comparing different freezing methods for biopsy samplings in the field. The latter was done to assess the quality of biopsy material obtained using (a) liquid nitrogen (flash frozen) or (b) frozen in dry ice and then compared with large muscle pieces flash-frozen in liquid nitrogen as controls.

\section{Sampling 2-Wild salmon}

Nine wild salmon were angled in River Dale (location; $60.653^{\circ} \mathrm{N}, 5.809^{\circ} \mathrm{E}$ ) during autumn 2011 and kept in a $3 \mathrm{~m}$ diameter fiberglass tank supplied with running water until 20 November, when they were killed and tissue samples from snout, muscle and adipose fin were taken. Mean fork length $( \pm$ SEM) was $72 \pm 4.0 \mathrm{~cm}$. They were not fed during this period.

\section{Analysis}

TOT was extracted according to Folch et al. (1957). The lipid classes were quantified using $10 \times 10 \mathrm{~cm}$ HPTLC plates (Merck) and the double development system of Olsen \& Henderson (1989). TAG was separated using hexane:diethyl ether:acetic acid (80:20:2) as developing solvent (Olsen \& Henderson 1989), visualised using $0.2 \% 2^{\prime}, 7^{\prime}$-dichlorofluorescin in $95 \%$ ethanol spray and viewed under ultraviolet-light for detection. The TAG was scraped off the plate and subjected to the sulphuric acid catalysed transesterification of Christie (1982), extracted into hexane and stored at $-80^{\circ} \mathrm{C}$ until analysed. Quantitative analysis of fatty acid methyl esters (FAME) was carried out by gas liquid chromatography using a HP 5890 gas chromatograph, autoinjector and splittless injection. The column used was a J\&N Scientific Inc. DB-23 fused silica column ( $30 \mathrm{~m} \times 0.25 \mathrm{~mm}$ i.d.). The oven temperature was programmed to rise from 50 to $170^{\circ} \mathrm{C}$ at $25^{\circ} \mathrm{C} \mathrm{min}^{-1}$, and then to $210^{\circ} \mathrm{C}$ at $1.5^{\circ} \mathrm{C} \mathrm{min}^{-1}$, with a final holding time of $5 \mathrm{~min}$. Separated components were identified with reference to authentic standards.

\section{Statistics}

Data were analysed statistically with SPSS Ver. 21.0 for personal computers. Prior to statistical testing, all data were checked for homogeneity of variances by the Levene test, and, where necessary, they were subjected to arcsine transformations. Numerical results are expressed as means $( \pm$ SEM) unless otherwise stated. Data from different tissues were compared using 1- or 2-way ANOVA, where appropriate, and subjected to Tukey's multiple range test. The level of statistical significance was set at $\mathrm{p}<0.05$. Sirius Version 9.0@, Pattern Recognition Systems (www.prs.no), was used for principal component analysis (PCA).

\section{RESULTS}

The lipid content and lipid class composition varied between the farmed (Sampling 1) and wild Salmo salar (Sampling 2) and between the tissue samples (Table 1). Muscle from maturing fish held in a sea cage at Matre was high in lipid $(32.8 \pm 1.6 \%)$. Using biopsies tended to lower the lipid content of the samples somewhat. The adipose fin was lean, with only $1.1 \pm 1.6 \%$ lipid of wet weight. The lipid class compo- 
Table 1. Salmo salar. Lipid content and lipid class composition of the fish collected in Samplings 1 (farmed salmon) and 2 (wild salmon). Lipid contents are shown as means $( \pm$ SEM). Potential differences between the tissues were assessed by 1 -way ANOVA. Significance was accepted at $p<0.05$. Numbers within each line not sharing common superscript letters are significantly different. Lipid class composition is the mean of 5 fish. Farmed fish: maturing fish at Matre Research Station, $\mathrm{n}=15$; wild fish: wild fish returning to the Dale River for spawning, $\mathrm{n}=9$; biopsynitrogen, biopsy-dry ice: muscle biopsies frozen immediately after sampling in liquid nitrogen or dry ice; TAG: triacylglycerols; PL: polar lipid (sum of phosphatidyl-ethanolamine, -serine, -inositol, -choline and lysophosphatidylcholine)

\begin{tabular}{|c|c|c|c|c|}
\hline \multicolumn{5}{|c|}{ Lipid content (percent wet weight) } \\
\hline Farmed fish & $\begin{array}{c}\text { Muscle } \\
32.8 \pm 1.6^{\mathrm{a}}\end{array}$ & $\begin{array}{c}\text { Biopsy-nitrogen } \\
25.0 \pm 1.4^{\mathrm{b}}\end{array}$ & $\begin{array}{c}\text { Biopsy-dry ice } \\
28.1 \pm 1.5^{\mathrm{ab}}\end{array}$ & $\begin{array}{c}\text { Adipose fin } \\
1.1 \pm 1.6^{c}\end{array}$ \\
\hline Wild fish & $\begin{array}{c}\text { Muscle } \\
5.0 \pm 1.0^{\mathrm{a}}\end{array}$ & $\begin{array}{c}\text { Snout } \\
10.3 \pm 1.0^{\mathrm{b}}\end{array}$ & & $\begin{array}{c}\text { Adipose fin } \\
1.7 \pm 1.1^{\mathrm{a}}\end{array}$ \\
\hline \multicolumn{5}{|c|}{ Lipid class composition (percent of total lipid) } \\
\hline Farmed fish & Muscle & & & Adipose fin \\
\hline TAG & $91.8 \pm 0.5^{\mathrm{a}}$ & & & $19.8 \pm 5.6^{\mathrm{b}}$ \\
\hline PL & $4.4 \pm 0.7^{\mathrm{a}}$ & & & $45.2 \pm 6.0^{\mathrm{b}}$ \\
\hline Wild fish & Muscle & Snout & & Adipose fin \\
\hline TAG & $83.8 \pm 2.2^{\mathrm{b}}$ & $92.3 \pm 4.1^{\mathrm{a}}$ & & $19.9 \pm 5.5^{\mathrm{c}}$ \\
\hline PL & $13.7 \pm 2.2^{\mathrm{b}}$ & $4.4 \pm 2.7^{\mathrm{a}}$ & & $45.2 \pm 6.0^{\mathrm{c}}$ \\
\hline
\end{tabular}

sition in muscle was dominated by TAG, comprising $91.8 \pm 0.5 \%$ of the lipid with only $4.4 \pm 0.7 \%$ being phospholipids. The adipose fin had $19.8 \pm 5.6 \%$ as TAG and $45.2 \pm 6.0 \%$ as phospholipids, with the remaining lipid being mainly sterol esters/wax esters and cholesterol (data not shown). Maturing wild fish returning to rivers to spawn had low muscle lipid levels $(5.0 \pm 1.0 \%)$. Adipose fin lipid was again $<2 \%$, while snout had a relatively high lipid content $(10.3 \pm 1.0 \%)$. The TAG level was clearly related to tissue lipid and was highest in snout lipid $(92.3 \pm 4.1 \%$ of lipid), lower in muscle $(83.8 \pm 2.2 \%$ of lipid $)$ and lowest in adipose fin $(19.9 \pm 5.5 \%)$. Total polar lipids were $4.4 \pm 2.7 \%, 13.7 \pm 2.2 \%$ and $45.2 \pm 6.0 \%$ in the respective tissues.

The FAME composition of the diet-the TAG and TOT of adipose fin and muscle of maturing farmed salmon (Sampling 1) - are shown in Table 2 . The data clearly showed

Table 2. Salmo salar. Fatty acid composition in the diet and in the adipose fin and muscle triacylglycerols (TAG) and total lipids (TOT) of maturing Atlantic salmon fed on a defined diet over 12 mo (percent of fatty acids). Data are means ( \pm SEM) of 14 fish. Potential differences between the tissues were assessed by 2-way ANOVA and Tukey's post hoc test. Main effects are given in the right columns - Tissue: effect of adipose fin and muscle; TAG: effect of TAG or TOT fatty acid methyl ester composition; Tissue $\times$ TAG: interaction of the 2; SFA: saturated fatty acids; MUFA: monounsaturated fatty acids; PUFA: polyunsaturated fatty acids. Significance was accepted at $\mathrm{p}<0.05$. Numbers within each line not sharing common superscript letters are significantly different: ${ }^{* * *} \mathrm{p}<0.001,{ }^{* *} \mathrm{p}<0.01,{ }^{*} \mathrm{p}<0.05$

\begin{tabular}{|c|c|c|c|c|c|c|c|c|}
\hline \multirow[t]{2}{*}{ Fatty acid } & \multirow[t]{2}{*}{ Diet } & \multicolumn{2}{|c|}{ Adipose fin } & \multicolumn{2}{|c|}{ Muscle } & \multicolumn{3}{|c|}{ Statistics } \\
\hline & & TAG & TOT & TAG & TOT & Tissue & TAG & Tissue $\times$ TAG \\
\hline $14: 0$ & 2.5 & $1.7 \pm 0.1^{\mathrm{a}}$ & $1.7 \pm 0.1^{\mathrm{a}}$ & $2.4 \pm 0.0^{\mathrm{c}}$ & $2.2 \pm 0.0^{\mathrm{b}}$ & $* * *$ & $* * *$ & - \\
\hline $16: 0$ & 9.0 & $8.8 \pm 0.8^{a}$ & $14.6 \pm 0.7^{\mathrm{b}}$ & $9.6 \pm 0.1^{\mathrm{a}}$ & $9.2 \pm 0.1^{\mathrm{a}}$ & $* * *$ & $* *$ & $* * *$ \\
\hline $16: 1 n-7$ & 3.1 & $2.5 \pm 0.1^{\mathrm{b}}$ & $2.0 \pm 0.2^{\mathrm{a}}$ & $3.2 \pm 0.0^{\mathrm{c}}$ & $3.0 \pm 0.0^{\mathrm{bc}}$ & $* * *$ & $* * *$ & $* * *$ \\
\hline $18: 0$ & 2.5 & $4.2 \pm 0.7^{\mathrm{ab}}$ & $8.2 \pm 0.7^{\mathrm{c}}$ & $2.7 \pm 0.1^{\mathrm{a}}$ & $5.4 \pm 0.1^{b}$ & $* * *$ & $* * *$ & $* * *$ \\
\hline $18: 1 n-9$ & 43.0 & $41.7 \pm 2.2^{\mathrm{a}}$ & $27.0 \pm 1.9^{\mathrm{b}}$ & $41.8 \pm 0.3^{\mathrm{a}}$ & $36.5 \pm 0.5^{\mathrm{a}}$ & $* * *$ & $* * *$ & $* * *$ \\
\hline $18: 1 n-7$ & 2.8 & $3.1 \pm 0.1^{\mathrm{b}}$ & $2.2 \pm 0.1^{\mathrm{a}}$ & $2.9 \pm 0.1^{b}$ & $2.3 \pm 0.0^{\mathrm{a}}$ & - & $* * *$ & $* * *$ \\
\hline $18: 2 n-6$ & 14.8 & $11.7 \pm 0.6^{\mathrm{b}}$ & $7.8 \pm 0.6^{\mathrm{a}}$ & $13.2 \pm 0.2^{\mathrm{bc}}$ & $13.6 \pm 0.2^{\mathrm{c}}$ & $* * *$ & $* * *$ & $* * *$ \\
\hline $18: 3 n-6$ & 0.1 & $0.1 \pm 0.0^{\mathrm{b}}$ & $0.1 \pm 0.0^{\mathrm{a}}$ & $0.2 \pm 0.0^{\mathrm{b}}$ & $0.1 \pm 0.0^{\mathrm{b}}$ & $* * *$ & $* *$ & $* * *$ \\
\hline $18: 3 n-3$ & 5.4 & $3.9 \pm 0.3^{b}$ & $2.3 \pm 0.3^{\mathrm{a}}$ & $4.6 \pm 0.1^{\mathrm{c}}$ & $5.1 \pm 0.1^{\mathrm{c}}$ & $* * *$ & & $* * *$ \\
\hline $18: 4 n-3$ & 0.5 & $0.5 \pm 0.1^{\mathrm{a}}$ & $0.5 \pm 0.0^{\mathrm{a}}$ & $0.7 \pm 0.0^{\mathrm{b}}$ & $0.9 \pm 0.0^{\mathrm{C}}$ & $* * *$ & - & $* * *$ \\
\hline $20: 1 n-9$ & 3.4 & $3.1 \pm 0.2^{\mathrm{a}}$ & $2.6 \pm 0.7^{b}$ & $3.6 \pm 0.1$ & $3.2 \pm 0.1$ & - & * & - \\
\hline $20: 2 n-6$ & 1.1 & $1.2 \pm 0.1^{\mathrm{b}}$ & $0.9 \pm 0.1^{\mathrm{a}}$ & $1.1 \pm 0.0^{\mathrm{ab}}$ & $1.1 \pm 0.0^{\mathrm{b}}$ & - & $* * *$ & $* * *$ \\
\hline $20: 3 n-6$ & 0.2 & $0.4 \pm 0.0^{\mathrm{b}}$ & $0.5 \pm 0.1^{\mathrm{c}}$ & $0.3 \pm 0.0^{\mathrm{a}}$ & $0.3 \pm 0.0^{\mathrm{ab}}$ & $* * *$ & $* * * *$ & $* * *$ \\
\hline $20: 4 n-6$ & 0.4 & $0.7 \pm 0.3^{\mathrm{a}}$ & $2.9 \pm 0.4^{b}$ & $0.3 \pm 0.0^{\mathrm{a}}$ & $0.3 \pm 0.0^{\mathrm{a}}$ & $* * *$ & $* * *$ & $* * *$ \\
\hline $20: 3 n-3$ & 0.2 & $0.4 \pm 0.0^{\mathrm{b}}$ & $0.3 \pm 0.0^{\mathrm{a}}$ & $0.4 \pm 0.0^{\mathrm{b}}$ & $0.5 \pm 0.0^{\mathrm{b}}$ & $* * *$ & $* * *$ & $* * *$ \\
\hline $20: 4 n-3$ & 1.0 & $0.9 \pm 0.1^{b}$ & $0.8 \pm 0.0^{\mathrm{a}}$ & $0.9 \pm 0.0^{\mathrm{b}}$ & $1.1 \pm 0.4^{\mathrm{c}}$ & $* * *$ & - & $* * *$ \\
\hline $20: 5 n-3$ & 2.8 & $3.5 \pm 0.5^{\mathrm{a}}$ & $6.7 \pm 0.6^{b}$ & $2.4 \pm 0.1^{\mathrm{a}}$ & $3.3 \pm 0.1^{\mathrm{a}}$ & $* * *$ & $* * *$ & $* * *$ \\
\hline $22: 1 n-11$ & 1.5 & $1.5 \pm 0.2^{\mathrm{b}}$ & $0.7 \pm 0.2^{\mathrm{a}}$ & $1.9 \pm 0.1^{\mathrm{b}}$ & $1.8 \pm 0.1^{\mathrm{b}}$ & $* * *$ & $* * *$ & $* * *$ \\
\hline $22: 5 n-3$ & 0.4 & $1.4 \pm 0.1^{\mathrm{a}}$ & $2.2 \pm 0.1^{\mathrm{b}}$ & $1.4 \pm 0.1^{\mathrm{a}}$ & $1.8 \pm 0.1^{\mathrm{a}}$ & $* *$ & $* * *$ & $* * *$ \\
\hline $22: 6 n-3$ & 3.0 & $4.5 \pm 1.1^{\mathrm{a}}$ & $11.8 \pm 1.0^{\mathrm{b}}$ & $3.7 \pm 0.1^{\mathrm{a}}$ & $5.3 \pm 0.2^{\mathrm{a}}$ & $* * *$ & $* * *$ & $* * *$ \\
\hline SFA & 14.9 & $16.4 \pm 1.5^{\mathrm{a}}$ & $25.5 \pm 1.3^{\mathrm{b}}$ & $15.4 \pm 0.1^{\mathrm{a}}$ & $17.6 \pm 0.3^{\mathrm{a}}$ & $* * *$ & $* * *$ & $* * *$ \\
\hline MUFA & 53.5 & $53.8 \pm 2.7^{a}$ & $37.0 \pm 2.4^{\mathrm{b}}$ & $55.0 \pm 0.2^{\mathrm{a}}$ & $48.4 \pm 0.5^{\mathrm{a}}$ & $* * *$ & $* * *$ & $* * *$ \\
\hline PUFA & 31.6 & $29.8 \pm 1.3^{\mathrm{a}}$ & $37.5 \pm 1.2^{\mathrm{C}}$ & $29.6 \pm 0.2^{\mathrm{a}}$ & $33.9 \pm 0.6^{b}$ & $* * *$ & $* * *$ & $* * *$ \\
\hline$n-3$ & 14.8 & $15.1 \pm 1.5^{\mathrm{ab}}$ & $24.7 \pm 1.4^{\mathrm{C}}$ & $14.2 \pm 0.2^{\mathrm{a}}$ & $18.0 \pm 0.4^{\mathrm{b}}$ & $* * *$ & $* * *$ & $* * *$ \\
\hline$n-6$ & 16.7 & $14.7 \pm 0.3^{\mathrm{b}}$ & $12.9 \pm 0.3^{\mathrm{a}}$ & $15.5 \pm 0.1^{\mathrm{bc}}$ & $15.9 \pm 0.3^{\mathrm{c}}$ & $* * *$ & ${ }^{* *}$ & $* * *$ \\
\hline
\end{tabular}


that FAME compositions were dependent on both analysis method (TAG/TOT) and tissue. In general, 16:0, 18:0, 20:5n-3 and 22:6n-3 tended to increase in TOT compared to TAG, concomitant with a reduction in 18:1n-9. This led to a significant increase in PUFAs and particularly in the n-3 PUFA in TOT compared to TAG. The effects were rather pronounced for adipose fin, with significant increases $(\mathrm{p}<$ $0.05)$ in $16: 0,18: 0,20: 4 n-6,20: 5 n-3$ and $22: 6 n-3$, and reductions of $18: 1 n-9,18: 2 n-$ $6,18: 3 n-3,20: 1 n-9$ and $22: 1 n-11$ in TOT compared to TAG. For muscle there was a similar tendency, but the effects were less pronounced, and significant only for 18:0, n-3 and total PUFAs.

Principal component (PC) plots of individual fish FAMEs (TOT and TAG) of farmed fish (muscle and adipose fin) showed that PC1 accounted for $94 \%$ of the variation and PC2 accounted for only $3.4 \%$ (Fig. 1). The clustering of the individuals shows adipose fin TOT deviates strongly from both adipose fin TAG and muscle (TOT and TAG). The clustering of FAMEs on PC2 separates muscle TOT from adipose fin TAG. PC1 can be explained mainly as a contrast between 16:0, $18: 0,20: 4 n-6,20: 5 n-3$ and 22:6n-3 and the remaining fatty acids, while PC2 shows a negative weighting for $18: 1 n-9$ and a positive weighting for $18: 2 n-6$ and $18: 3 n-3$ (Fig. 2).

The FAMEs of snout, muscle and adipose fin of wild maturing Atlantic salmon returning to the Dale River showed the same pattern of change as in the TOT and TAG levels of the farmed fish (Table 3). In particular, in TOT, there was a general increase in 16:0, 18:0, 20:5n-3 and 22:6n-3 compared to TAG and a reduction in 18:1n-9, 20:1n-9 and 22:1n-11. This led to increased levels of saturated fatty acids (SFA), total PUFA and n-3 and reductions in monoenes. When comparing TAG only, muscle deviated most from snout and adipose fin, particularly with lower levels of 16:0 and 20:5n-3 and higher levels of 20:1n-9 and 22:1n-11.

The first 2 PCs of individual fish FAMEs of wild mature Atlantic salmon returning to the Dale River for spawning (Sampling 2), accounted for $90.4 \%$ of

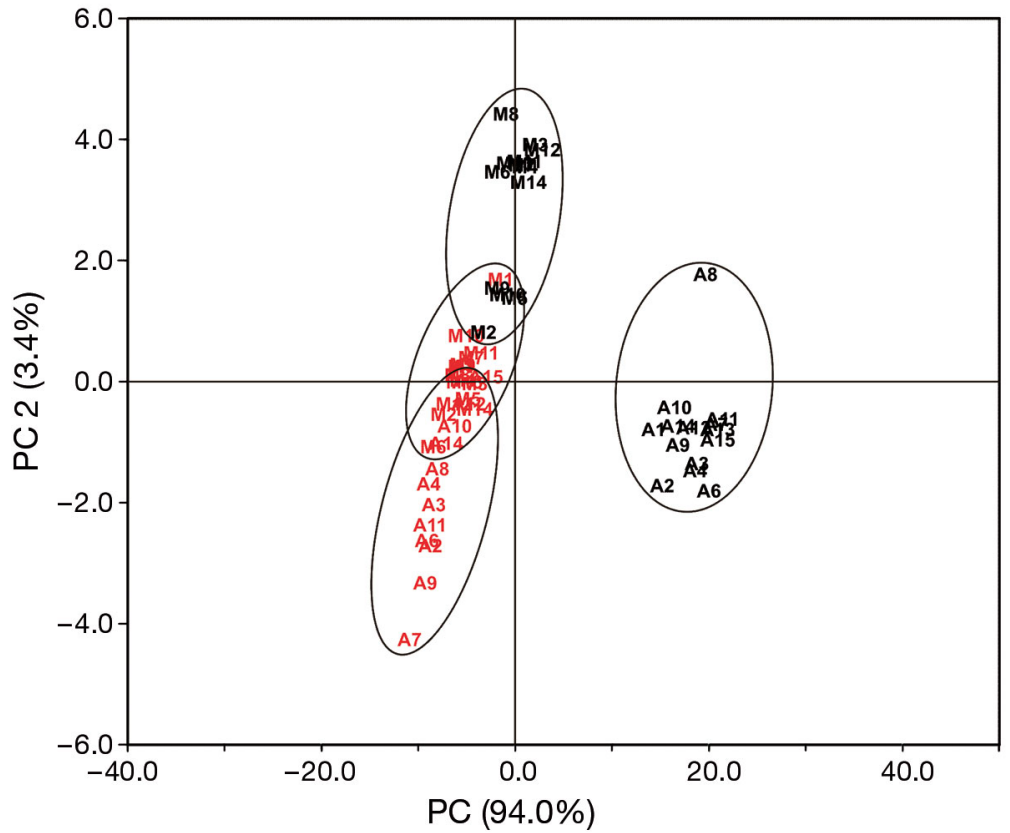

Fig. 1. Salmo salar. Score plot of principal component (PC) analysis of fatty acid methyl esters (FAME) in the muscle (M) and adipose fin (A) in farmed salmon. Black letters: total lipid FAMEs; red letters: triacylglycerols. Numbers in the alphanumeric codes refer to specific individuals

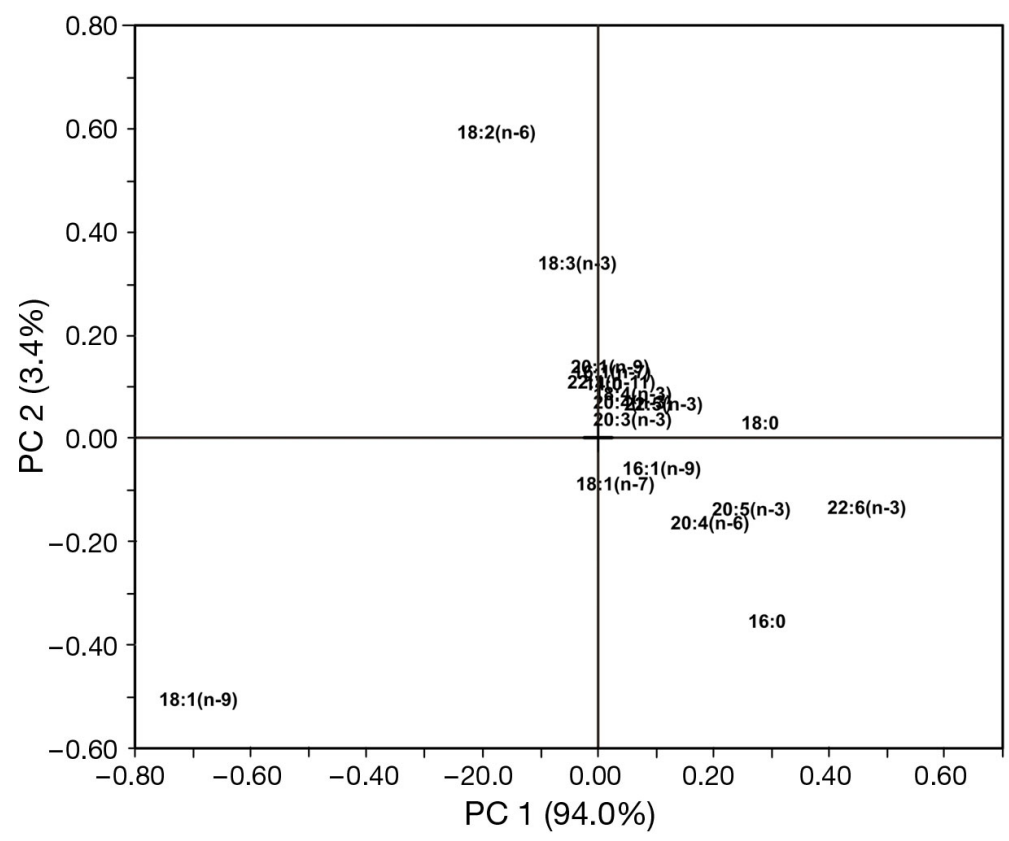

Fig. 2. Salmo salar. Loading plot of principal component (PC) analysis built on fatty acids in total lipids and triacylglycerols in the adipose fin and muscle of farmed salmon (see score plot in Fig. 1). Fatty acids closer to the origin are not shown

the variation (Fig. 3). PC1 accounted for $65.7 \%$ of the variation, and PC2, for $24.7 \%$. For PC1, TOT always gave a more positive weighting compared to TAG, regardless of the tissue. On a tissue level, adipose fin 
Table 3. Salmo salar. Fatty acid composition in the snout, muscle and adipose fins triacylglycerols (TAG) and total lipids (TOT) of wild Atlantic salmon caught upon entering the Dale River (percent of fatty acids). Data are means ( \pm SEM) of 9 fish. Potential differences between the tissues were assessed by 2-way ANOVA and Tukey's post hoc test. Main effects are given in right columns-tissue: effect of adipose fin, snout and muscle; TAG: effect of TAG or TOT fatty acid methyl ester composition; Tissue $\times$ TAG: interaction of the 2; SFA: saturated fatty acids; MUFA: monounsaturated fatty acids; PUFA: polyunsaturated fatty acids. Significance was accepted at $p<0.05$. Numbers within each line not sharing common superscript letters are significantly different: ${ }^{* *} \mathrm{p}<0.001,{ }^{* *} \mathrm{p}<0.01,{ }^{*} \mathrm{p}<0.05$

\begin{tabular}{|c|c|c|c|c|c|c|c|c|c|}
\hline \multirow[t]{2}{*}{ Fatty acid } & \multicolumn{2}{|c|}{ Snout } & \multicolumn{2}{|c|}{ Muscle } & \multicolumn{2}{|c|}{ Adipose fin } & \multicolumn{3}{|c|}{ Statistics } \\
\hline & TAG & TOT & TAG & TOT & TAG & TOT & Tissue & TAG & Tissue $\times$ TAG \\
\hline $14: 0$ & $3.5 \pm 0.2^{\mathrm{a}}$ & $3.7 \pm 0.1^{\mathrm{a}}$ & $3.6 \pm 0.3^{a}$ & $3.1 \pm 0.2^{\mathrm{ab}}$ & $3.0 \pm 0.3^{\mathrm{ab}}$ & $2.3 \pm 0.2^{\mathrm{a}}$ & $* * *$ & - & - \\
\hline $16: 0$ & $12.8 \pm 0.6^{\mathrm{bc}}$ & $12.8 \pm 0.5^{\mathrm{bc}}$ & $8.9 \pm 0.9^{a}$ & $11.0 \pm 0.4^{\mathrm{ab}}$ & $11.7 \pm 0.6^{\mathrm{b}}$ & $14.6 \pm 0.6^{\mathrm{c}}$ & $* * *$ & $* *$ & - \\
\hline $16: 1 n-7$ & $5.5 \pm 0.3^{\mathrm{c}}$ & $4.7 \pm 0.3^{\mathrm{abc}}$ & $4.3 \pm 0.3^{\mathrm{abc}}$ & $3.5 \pm 0.3^{\mathrm{ab}}$ & $4.8 \pm 0.3^{\mathrm{bc}}$ & $3.3 \pm 0.3^{\mathrm{a}}$ & $* *$ & $* * *$ & - \\
\hline $18: 0$ & $3.0 \pm 0.2^{\mathrm{a}}$ & $5.9 \pm 0.2^{\mathrm{b}}$ & $2.5 \pm 0.3^{\mathrm{a}}$ & $6.1 \pm 0.2^{\mathrm{b}}$ & $3.2 \pm 0.2^{\mathrm{a}}$ & $8.5 \pm 0.5^{\mathrm{c}}$ & $* * *$ & $* * *$ & * \\
\hline $18: 1 n-9$ & $22.5 \pm 1.0^{\mathrm{ab}}$ & $18.9 \pm 1.1^{\mathrm{a}}$ & $22.9 \pm 1.5^{\mathrm{ab}}$ & $17.4 \pm 1.4^{\mathrm{a}}$ & $24.9 \pm 1.7^{b}$ & $17.3 \pm 0.9^{\mathrm{a}}$ & - & $* * *$ & - \\
\hline $18: 1 n-7$ & $3.6 \pm 0.2^{\mathrm{b}}$ & $2.8 \pm 0.2^{\mathrm{ab}}$ & $3.2 \pm 0.3^{\mathrm{ab}}$ & $2.6 \pm 0.2^{\mathrm{a}}$ & $3.1 \pm 0.2^{\mathrm{ab}}$ & $2.7 \pm 0.1^{\mathrm{a}}$ & - & $* *$ & - \\
\hline $18: 2 n-6$ & $1.6 \pm 0.0^{\mathrm{ab}}$ & $1.4 \pm 0.0^{\mathrm{b}}$ & $1.7 \pm 0.1^{\mathrm{c}}$ & $1.5 \pm 0.1^{\mathrm{b}}$ & $1.6 \pm 0.0^{\mathrm{bc}}$ & $1.1 \pm 0.2^{\mathrm{a}}$ & $* * *$ & $* * *$ & * \\
\hline $18: 3 n-6$ & $0.1 \pm 0.0$ & $0.1 \pm 0.0$ & $0.1 \pm 0.0$ & $0.1 \pm 0.0$ & $0.1 \pm 0.0$ & $0.1 \pm 0.1$ & - & - & - \\
\hline $18: 3 n-3$ & $0.9 \pm 0.1^{\mathrm{ab}}$ & $1.5 \pm 0.5^{\mathrm{b}}$ & $0.8 \pm 0.1^{\mathrm{ab}}$ & $0.9 \pm 0.1^{\mathrm{ab}}$ & $0.9 \pm 0.1^{\mathrm{ab}}$ & $0.6 \pm 0.1^{\mathrm{a}}$ & * & - & - \\
\hline $18: 4 n-3$ & $1.4 \pm 0.2$ & $1.7 \pm 0.3$ & $1.0 \pm 0.2$ & $1.3 \pm 0.3$ & $1.3 \pm 0.3$ & $1.1 \pm 0.2$ & - & - & - \\
\hline $20: 1 n-9$ & $11.4 \pm 0.8^{\mathrm{b}}$ & $9.3 \pm 0.9^{\mathrm{ab}}$ & $16.5 \pm 1.3^{\mathrm{c}}$ & $12.6 \pm 0.9^{\mathrm{bc}}$ & $10.7 \pm 0.6^{\mathrm{b}}$ & $6.1 \pm 0.8^{\mathrm{a}}$ & $* * *$ & $* * *$ & - \\
\hline $20: 2 n-6$ & $0.4 \pm 0.0$ & $1.0 \pm 0.6$ & $0.4 \pm 0.0$ & $0.3 \pm 0.0$ & $0.4 \pm 0.0$ & $0.4 \pm 0.1$ & - & - & - \\
\hline $20: 3 n-6$ & $0.1 \pm 0.0^{\mathrm{ab}}$ & $0.1 \pm 0.0^{\mathrm{abc}}$ & $0.2 \pm 0.0^{\mathrm{bc}}$ & $0.1 \pm 0.0^{c}$ & $0.1 \pm 0.0^{\mathrm{a}}$ & $0.1 \pm 0.0^{\mathrm{abc}}$ & $* *$ & * & - \\
\hline $20: 4 n-6$ & $0.4 \pm 0.0^{\mathrm{a}}$ & $0.6 \pm 0.1^{\mathrm{a}}$ & $0.4 \pm 0.0^{\mathrm{a}}$ & $0.5 \pm 0.1^{\mathrm{a}}$ & $0.5 \pm 0.1^{\mathrm{a}}$ & $2.1 \pm 0.4^{\mathrm{b}}$ & $* * *$ & $* * *$ & $* * *$ \\
\hline $20: 3 n-3$ & $0.2 \pm 0.0^{\mathrm{b}}$ & $0.2 \pm 0.0^{\mathrm{b}}$ & $0.1 \pm 0.0^{\mathrm{ab}}$ & $0.2 \pm 0.0^{\mathrm{ab}}$ & $0.2 \pm 0.0^{\mathrm{b}}$ & $0.1 \pm 0.0^{\mathrm{a}}$ & $* *$ & - & $* *$ \\
\hline $20: 4 n-3$ & $1.9 \pm 0.1$ & $2.1 \pm 0.2$ & $1.6 \pm 0.1$ & $2.0 \pm 0.1$ & $2.1 \pm 0.1$ & $1.7 \pm 0.1$ & - & - & * \\
\hline $20: 5 n-3$ & $4.7 \pm 0.3^{\mathrm{b}}$ & $6.0 \pm 0.4^{\mathrm{b}}$ & $2.8 \pm 0.3^{\mathrm{a}}$ & $5.0 \pm 0.4^{\mathrm{b}}$ & $5.9 \pm 1.3^{b}$ & $9.2 \pm 1.8^{\mathrm{c}}$ & $* * *$ & $* * *$ & - \\
\hline $22: 1 n-11$ & $10.1 \pm 0.7^{b}$ & $8.3 \pm 0.7^{\mathrm{ab}}$ & $14.4 \pm 1.1^{\mathrm{c}}$ & $11.2 \pm 0.7^{\mathrm{bc}}$ & $9.6 \pm 0.6^{b}$ & $4.9 \pm 0.8^{\mathrm{a}}$ & $* * *$ & $* * *$ & - \\
\hline $22: 5 n-3$ & $2.5 \pm 0.1^{\mathrm{a}}$ & $2.9 \pm 0.2^{\mathrm{ab}}$ & $2.6 \pm 0.1^{\mathrm{ab}}$ & $3.2 \pm 0.1^{\mathrm{b}}$ & $2.9 \pm 0.2^{\mathrm{ab}}$ & $3.1 \pm 0.2^{\mathrm{ab}}$ & - & $* *$ & - \\
\hline $22: 6 n-3$ & $8.0 \pm 0.5^{\mathrm{ab}}$ & $10.2 \pm 0.8^{\mathrm{bc}}$ & $6.4 \pm 0.6^{\mathrm{a}}$ & $12.4 \pm 1.1^{\mathrm{cd}}$ & $7.9 \pm 0.8^{\mathrm{ab}}$ & $15.0 \pm 1.1^{\mathrm{c}}$ & * & $* * *$ & * \\
\hline SFA & $20.0 \pm 0.7^{b c}$ & $23.8 \pm 0.8^{\mathrm{cd}}$ & $15.6 \pm 1.4^{\mathrm{a}}$ & $20.9 \pm 0.6^{\mathrm{bc}}$ & $18.9 \pm 0.7^{\mathrm{ab}}$ & $26.8 \pm 0.9^{\mathrm{d}}$ & $* * *$ & $* * *$ & - \\
\hline MUFA & $56.6 \pm 1.9^{\mathrm{cd}}$ & $46.8 \pm 2.1^{\mathrm{ab}}$ & $65.3 \pm 2.5^{\mathrm{d}}$ & $50.3 \pm 2.2^{\mathrm{bc}}$ & $56.5 \pm 2.1^{\mathrm{bcd}}$ & $37.2 \pm 2.7^{\mathrm{a}}$ & $* * *$ & $* * *$ & - \\
\hline PUFA & $23.3 \pm 1.2^{\mathrm{ab}}$ & $29.3 \pm 1.5^{\mathrm{b}}$ & $18.9 \pm 1.2^{\mathrm{a}}$ & $26.7 \pm 1.7^{b}$ & $24.5 \pm 1.6^{\mathrm{ab}}$ & $36.3 \pm 5.9^{\mathrm{c}}$ & $* * *$ & $* * *$ & - \\
\hline$n-3$ & $19.5 \pm 1.2^{\mathrm{ab}}$ & $24.6 \pm 1.6^{\mathrm{b}}$ & $15.4 \pm 1.2^{\mathrm{a}}$ & $24.9 \pm 1.7^{\mathrm{bc}}$ & $21.2 \pm 1.6^{\mathrm{ab}}$ & $30.9 \pm 1.5^{\mathrm{c}}$ & $* *$ & $* * *$ & - \\
\hline$n-6$ & $3.6 \pm 0.1^{\mathrm{ab}}$ & $4.2 \pm 0.8^{\mathrm{ab}}$ & $3.3 \pm 0.1^{\mathrm{a}}$ & $3.3 \pm 0.1^{\mathrm{a}}$ & $3.2 \pm 0.1^{\mathrm{a}}$ & $4.9 \pm 0.5^{\mathrm{b}}$ & - & $* *$ & * \\
\hline
\end{tabular}

TOT clustering caused positive weighting and muscle TAG caused a negative weighting. Snout was intermediate between the two. When variables were extracted, it was evident that PC1 was explained mainly as a positive contrast between 16:0, 18:0, 20:5n-3 and 22:6n-3 and as a negative contrast to the long-chain monoenes (18:1n-9, 20:1n-9 and 22:1n-9) (Fig. 4). PC2 is mainly explained as the inverse relationship between 18:1n-9 and 20:1n-9/22:1n-11.

The effect of biopsy methods on the TAG fatty acid composition of maturing farmed salmon maintained in cages at Matre Research Station is shown in Table 4. The first column is the dietary fatty acid composition. There were no significant effects of the sampling or freezing methods on fatty acid composition.

To compare adipose fin TOT and TAG of farmed (Sampling 1) and wild salmon (Sampling 2), a PCA plot was produced including these variables (Fig. 5). The first 2 PCs explained $97.1 \%$ of the variation. The TAG and TOT samples of the farmed fish data gave 2 small and distinctly separated clusters where TAG had a positive weighting with PC1 $(78.7 \%)$, while TOT was neutral. Wild fish TAG also tended to have a positive weighting compared to muscle TOT, but data were more scattered. For PC2 (18.4\%) TAG FAMEs had a positive weighting compared to TOT for both groups of fish. The variable loading for the extracted components showed a positive weighting in PC1 is mainly due to higher levels of $18: 1 n-9$ and $18: 2 n-6$ in a reverse relationship with 16:0, 18:0, 20:5n-3 and 22:6n-3 (Fig. 6). For PC2, the main positive weighting by $20: 1 \mathrm{n}-9$ and $22: 1 \mathrm{n}-11$ is reversed by a negative weighting of 16:0, 18:0, 22:6n-3 and 18:2n-6.

\section{DISCUSSION}

The lipid content in the tissues varied from around $1 \%$ of wet weight in adipose fin to $>30 \%$ in farmed maturing Salmo salar. Wild fish had considerably lower lipid content in muscle. This relates to the fact that maturing salmon become anorectic and invest a 


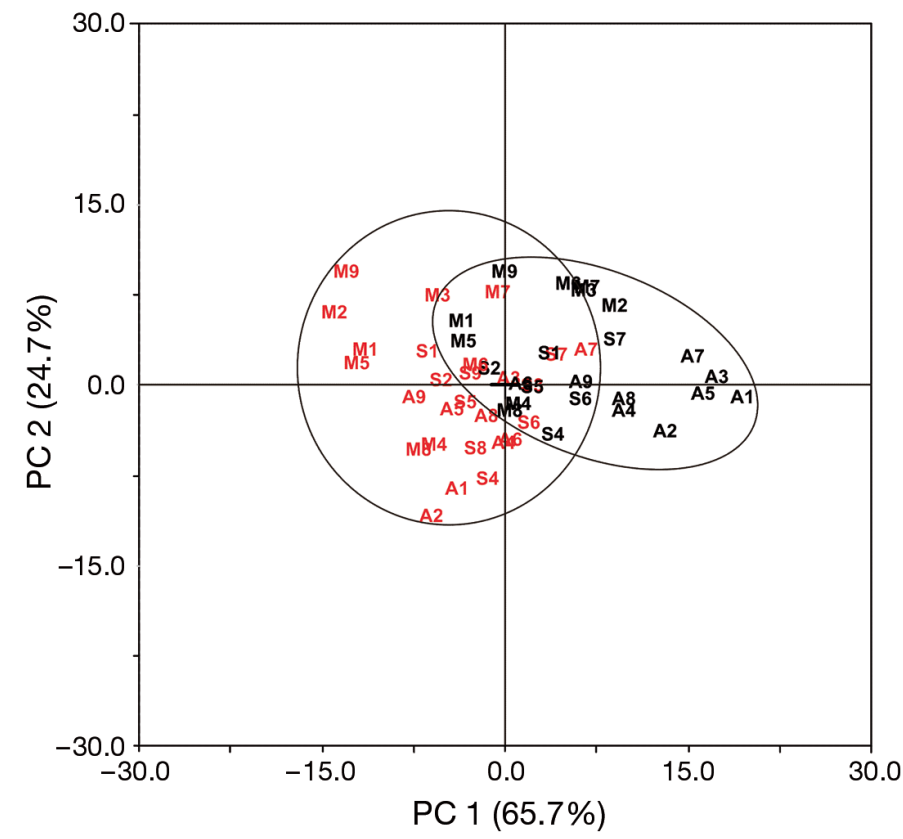

Fig. 3. Salmo salar. Score plot of principal component (PC) analysis of levels of fatty acid methyl esters (FAME) in total lipids (black) or triacylglycerols (red) in the adipose fin (A), snout (S) and muscle (M) samples of wild salmon. Numbers in the alphanumeric codes refer to specific individuals

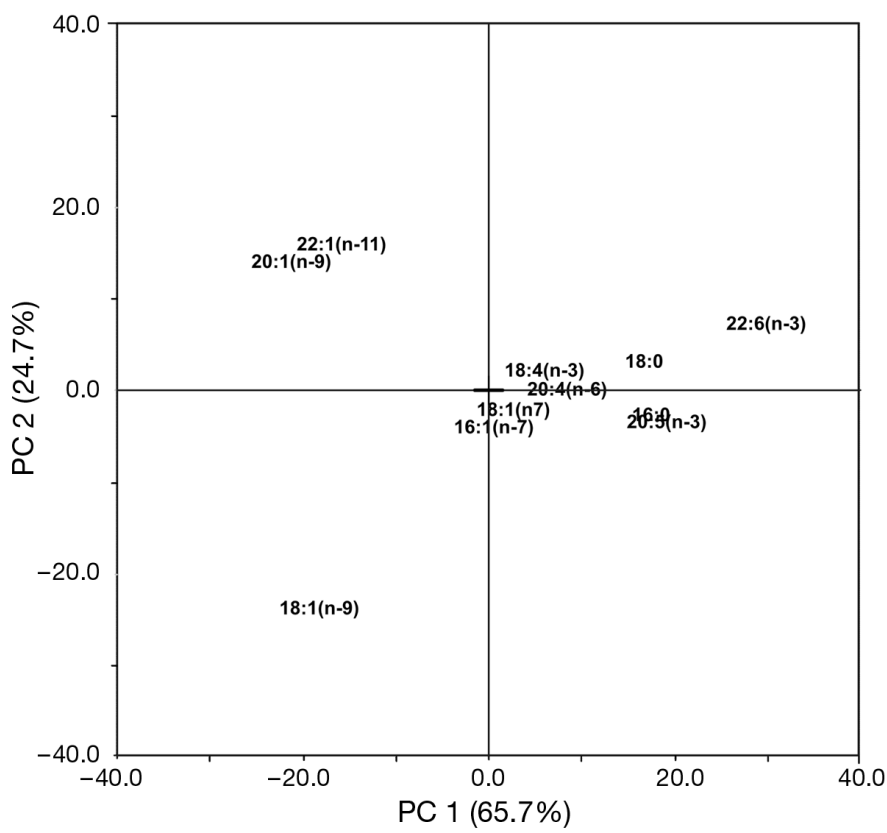

Fig. 4. Salmo salar. Loading plot of principal component (PC) analysis of fatty acids in total lipids and triacylglycerols in the adipose fin and muscle of wild salmon (see score plot in Fig. 3). Fatty acids closer to the origin are not shown

large part of their energy into gonad maturation and swimming to the spawning grounds (Aksnes et al. 1986, Kadri et al. 1996). The lowest level of lipid that we have recorded in wild maturing salmon is $1.5 \%$ muscle lipid (data not shown). It was also interesting to note that snout had high lipid contents even in fish with low muscle lipid. In many release experiments and marking programmes salmon snouts are tagged with a coded wire (Hand et al. 2010). Snouts/heads are then collected from salmon fisheries for analysis. Hence the material available for analysis is much greater than that available from muscle samples.

The minimum sample needed to obtain sufficient lipid material will therefore depend on the tissue and life stage of the fish, and the laboratory setup. We usually need $100 \mathrm{ng}$ of injected sample in our gas chromatograph to obtain good fatty acid traces. As we use autoinjectors requiring volumes of $50 \mu \mathrm{l}$, the amount of fatty acids required for a good resolution run is around $5 \mu \mathrm{g}$. This means that the minimum required lipid is around $10 \mu \mathrm{g}$ for lipid-rich samples and around twice that amount for lipid-poor tissues. Increasing sensitivity and manual injections could easily lower the required amount further. However, it should be taken into account that samples on occasion may need to be re-prepared and re-analysed. According to these considerations, it should be sufficient to sample $100 \mathrm{mg}$ of adipose fin to obtain $1 \mathrm{mg}$ of lipid, or $500 \mu \mathrm{g}$ TAG. For muscle tissue, $100 \mathrm{mg}$ would give anything from 5 to $30 \mathrm{mg}$ of lipid dependent on the nutritional status of the fish. This is in the range of material sampled with the biopsy needles (30 to $150 \mathrm{mg}$ ). At the lower end, this would provide a minimum of 4 to $5 \mathrm{mg}$ lipid content which is perfectly feasible to analyse for fatty acids. But, as a rule of thumb, we suggest a minimum amount of sample to be in the range of 60 to $100 \mathrm{mg}$ for muscle and 0.5 to $1.0 \mathrm{~g}$ for adipose fin.

Under normal circumstances, muscle biopsies should be taken into nitrogen for flash-freezing. However, as nitrogen may not always be available in the field, additional samples were taken to compare biopsies flash-frozen in liquid nitrogen with those frozen in dry ice, which is the more common field sampling method. The biopsy needles did not appear to cause major damage to the fish. A small incision in the skin before collecting the sample would ensure minimum damage. Regardless of the method chosen, however, the sampling process had no effect on the TAG fatty acid profiles.

Tissue fatty acid composition is significantly affected by diet (Henderson \& Tocher 1987, Bell et al. 2001, Olsen et al. 2003, 2004, Torstensen et al. 2005, Schlechtriem et al. 2007). But the direct effect is 
Table 4. Salmo salar. Triacylglycerol fatty acid composition (percent of fatty acids) of diet, control muscle and muscle biopsies (in liquid nitrogen or dry ice) of farmed sexually mature Atlantic salmon. Data are means $( \pm$ SEM) of 12 fish. Potential differences between the tissues were assessed by 1 -way ANOVA and Tukey's post hoc test. Significance was accepted at $p<0.05$. There were no significant differences between the sampling methods. Muscle control: large white muscle fraction flash-frozen in liquid nitrogen to serve as control to the biopsies; muscle biopsies: small samples stored immediately after sampling in liquid nitrogen or on dry ice; SFA: saturated fatty acids; MUFA: monounsaturated fatty acids; PUFA: polyunsaturated fatty acids

\begin{tabular}{|c|c|c|c|c|}
\hline \multirow{2}{*}{$\begin{array}{l}\text { Fatty } \\
\text { acid }\end{array}$} & \multirow{2}{*}{ Diet } & \multirow{2}{*}{$\begin{array}{l}\text { Muscle } \\
\text { control }\end{array}$} & \multicolumn{2}{|c|}{ Muscle biopsies } \\
\hline & & & Nitrogen & Dry ice \\
\hline $14: 0$ & 2.5 & $2.4 \pm 0.0$ & $2.4 \pm 0.0$ & $2.4 \pm 0.0$ \\
\hline $16: 0$ & 9.0 & $9.6 \pm 0.1$ & $9.8 \pm 0.6$ & $9.6 \pm 0.1$ \\
\hline $16: 1 n-7$ & 3.1 & $3.2 \pm 0.0$ & $3.2 \pm 0.0$ & $3.2 \pm 0.0$ \\
\hline $18: 0$ & 2.5 & $2.7 \pm 0.1$ & $2.8 \pm 0.1$ & $2.9 \pm 0.1$ \\
\hline $18: 1 n-9$ & 43.0 & $41.8 \pm 0.5$ & $41.8 \pm 0.5$ & $41.4 \pm 0.4$ \\
\hline $18: 1 n-7$ & 2.8 & $2.9 \pm 0.2$ & $2.8 \pm 0.1$ & $3.2 \pm 0.1$ \\
\hline $18: 2 n-6$ & 14.8 & $13.2 \pm 0.2$ & $12.9 \pm 0.2$ & $12.9 \pm 0.2$ \\
\hline $18: 3 n-6$ & 0.1 & $0.2 \pm 0.0$ & $0.1 \pm 0.0$ & $0.1 \pm 0.0$ \\
\hline $18: 3 n-3$ & 5.4 & $4.6 \pm 0.1$ & $4.5 \pm 0.0$ & $4.4 \pm 0.1$ \\
\hline $18: 4 n-3$ & 0.5 & $0.7 \pm 0.0$ & $0.7 \pm 0.0$ & $0.7 \pm 0.0$ \\
\hline $20: 1 n-9$ & 3.4 & $3.6 \pm 0.1$ & $3.8 \pm 0.7$ & $3.7 \pm 0.7$ \\
\hline $20: 2 n-6$ & 1.1 & $1.1 \pm 0.0$ & $1.0 \pm 0.1$ & $1.1 \pm 0.0$ \\
\hline $20: 3 n-6$ & 0.2 & $0.3 \pm 0.0$ & $0.3 \pm 0.1$ & $0.3 \pm 0.0$ \\
\hline $20: 4 n-6$ & 0.4 & $0.3 \pm 0.0$ & $0.3 \pm 0.0$ & $0.3 \pm 0.0$ \\
\hline $20: 3 n-3$ & 0.2 & $0.5 \pm 0.0$ & $0.4 \pm 0.0$ & $0.4 \pm 0.0$ \\
\hline $20: 4 n-3$ & 0.2 & $0.9 \pm 0.0$ & $0.9 \pm 0.0$ & $0.9 \pm 0.0$ \\
\hline $20: 5 n-3$ & 2.8 & $2.4 \pm 0.1$ & $2.4 \pm 0.1$ & $2.5 \pm 0.1$ \\
\hline $22: 1 n-11$ & 1.5 & $1.9 \pm 0.1$ & $2.1 \pm 0.1$ & $2.0 \pm 0.1$ \\
\hline $22: 5 n-3$ & 0.9 & $1.3 \pm 0.1$ & $1.4 \pm 0.0$ & $1.3 \pm 0.1$ \\
\hline $22: 6 n-3$ & 3.0 & $3.7 \pm 0.1$ & $3.8 \pm 0.1$ & $3.6 \pm 0.2$ \\
\hline SFA & 14.9 & $15.6 \pm 0.2$ & $15.7 \pm 0.2$ & $15.8 \pm 0.2$ \\
\hline MUFA & 53.5 & $54.9 \pm 0.3$ & $54.9 \pm 0.3$ & $55.4 \pm 0.3$ \\
\hline PUFA & 31.6 & $29.6 \pm 0.2$ & $29.4 \pm 0.2$ & $28.8 \pm 0.3$ \\
\hline$n-3$ & 14.8 & $14.2 \pm 0.2$ & $14.3 \pm 0.3$ & $13.8 \pm 0.3$ \\
\hline$n-6$ & 16.7 & $15.4 \pm 0.2$ & $15.1 \pm 0.1$ & $15.0 \pm 0.2$ \\
\hline
\end{tabular}

dependent on the type of lipid class. Phospholipids make up the majority of cell membranes, and their composition regulates cell function and membrane fluidity. This requires a stable membrane composition; thus, the synthesis and composition of phospholipids is under strict metabolic control (Henderson \& Tocher 1987, Olsen et al. 1991). The main fatty acids in PL are 16:0, 20:5n-3 and 22:6n-3, with variable amounts of 18:0, 18:1n-9 and 20:4n-6. Dietary lipids do affect PL composition (Olsen et al. 2003), but to a lesser extent than they affect TAG. Depot lipids are, on the other hand, reserves of energy and essential fatty acids, and, although some modification occurs, the fatty acid composition is generally highly dictated by diets (Henderson \& Tocher 1987, Olsen et al.

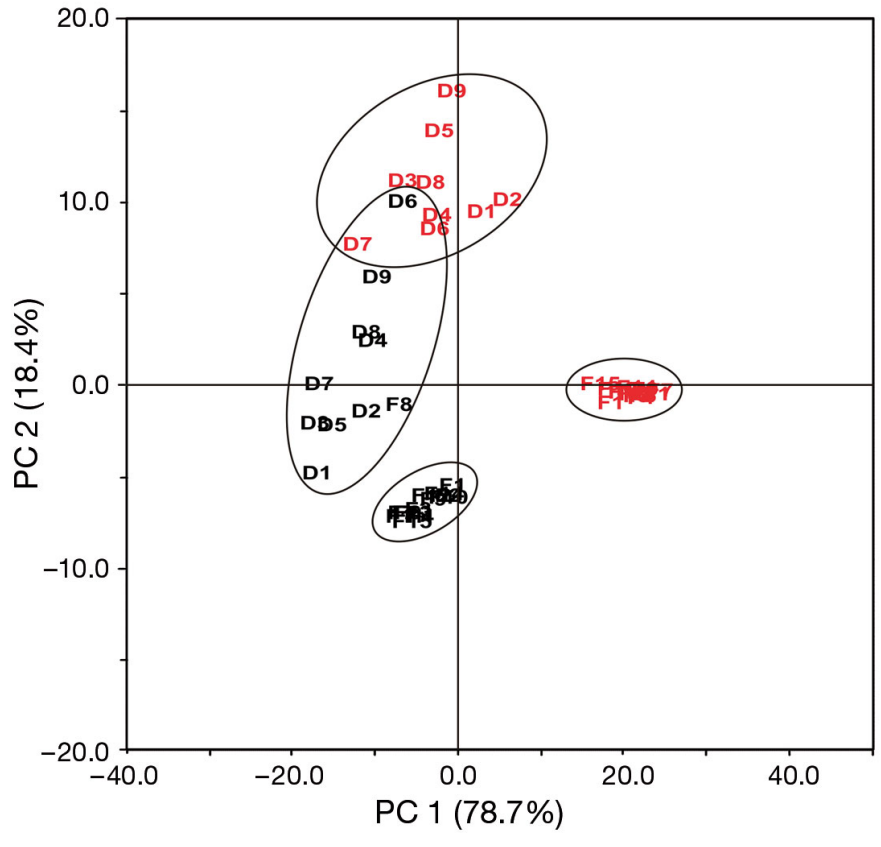

Fig. 5. Salmo salar. Score plot of principal component (PC) analysis of levels of fatty acids in total lipids (black) or triacylglycerols (red) in the adipose fin of farmed (F) and wild salmon from the Dale River (D). Numbers in the alphanumeric codes refer to specific individuals

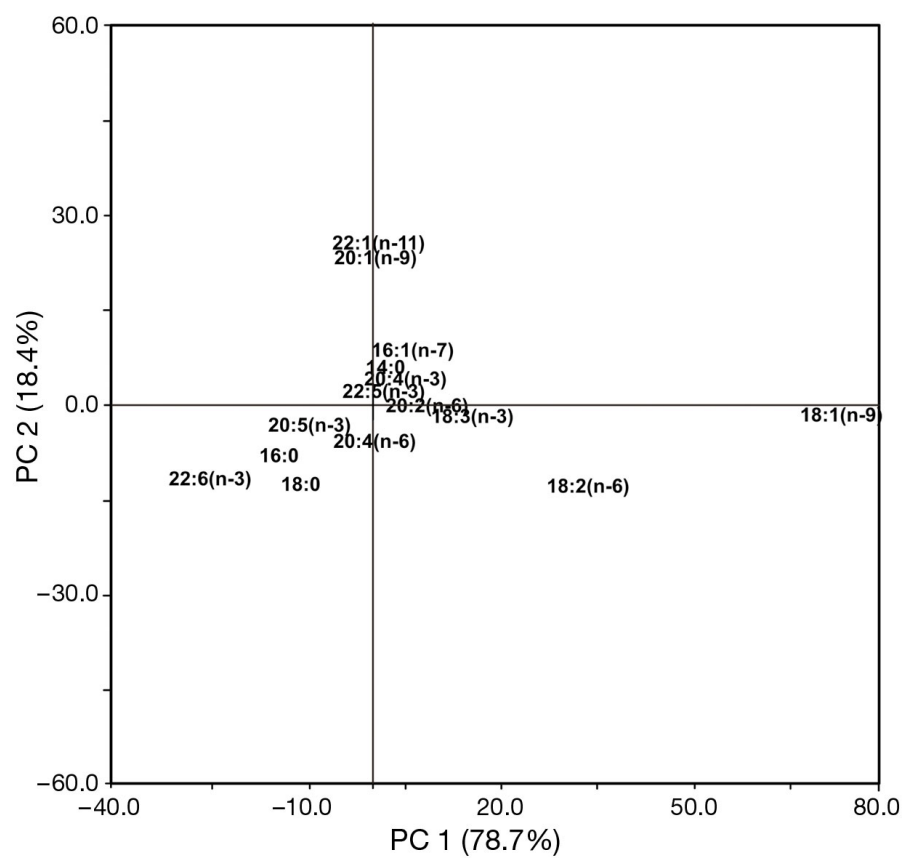

Fig. 6. Salmo salar. Loading plot of principal component (PC) analysis of fatty acids in total lipids and triacylglycerols in the adipose fin of farmed and wild salmon (see score plot in Fig. 5). Fatty acids closer to the origin are not shown 
1991, Corraze \& Kaushik 1999, Olsen \& Skilbrei 2010). This was also evident in the present study where TAG composition in all tissues examined in sea-cage-fed fish closely resembled the diet. In lean tissues, such as adipose fins in the present study, TAG would contribute to around one-third of the fatty acids, while two-thirds would originate from PL. In the muscle of these fish, TAG would contribute to $>90 \%$ of the total fatty acids, and the PL contribution would be less pronounced. This caused less difference between muscle TOT and TAG. This became especially clear in the PCA plots where the driving force separating adipose fin TOT from the other samples was due to elevated levels of the PL fatty acids 20:5n-3, 22:6n-3, 20:4n-6, 16:0 and 18:0 and lowered the content of the remaining fatty acids when compared to TAG. This change clearly moved the fatty acid profile away from the dietary profile. The small but notable inverse relationship between 18:2n-6 and $18: 1 n-9$ indicates that adipose fin TAG preferentially incorporates $18: 1 n-9$, but also that the level of 18:2n-6 may be a trait difference, as indicated previously for other fatty acids (Schlechtriem et al. 2007).

Analysing wild fish is obviously more challenging than analysing farmed fish as the former will have fed on different preys. Consequently, analysing average values will be of less significance. However, with regard to TOT and TAG comparisons, PCA plots again showed that the leaner the tissue, the more important PL fatty acids (16:0, 18:0, 20:5n-3 and $22: 6 n-3)$ become for the variation. Conversely, the more tissue lipid, the more important 18:1n-9, 20:1n-9 and $22: 1 \mathrm{n}-11$ become for the variation. These are dietary fatty acids describing a dietary history and are not extensively incorporated into PL. It thus appears, if we accept that TAG represents dietary history, that analysing FAME from TAG rather than TOT will give a better indication of previous feeding history. But, if tissues are lipid rich, both options could be chosen.

One application of fatty acid profiling is to study the foraging behaviour and escape history of escaped farmed fish (Olsen \& Skilbrei 2010, Abrantes et al. 2011). Modern farm diets have high inclusion levels of vegetable oils and, in some countries, also terrestrial lipids such as poultry fat. These oils typically have high contents of signature fatty acids like 18:2n-6 and 18:3n-3 which are only found in small amounts in natural diets. Canola oil is also popular to include in diets, as it contains high levels of 18:1n-9 and relatively low levels of plant PUFAs. Wild fish will, on the other hand, have variable contents of other fatty acids giving signatures to prey history. For example, many lower tropic level copepods and krill contain high levels of the long-chain alcohols like 20:1n-9 and 22:1n-11 (Falk-Petersen et al. 2009, Olsen et al. 2010) that are oxidised to fatty acids and deposited as fatty acids in TAG upon digestion. These are not incorporated into PL as readily as long-chain PUFAs. When adipose fins of farmed and wild fish were compared using PCA plots, the main fatty acids explaining the difference were 18:1n-9 and 18:2n-6, both very high in artificial diets. Wild fish were also clearly separated by their high content of 20:1n-9 and 22:1n-11. The distances were not always as clear using TOT FAME, and they were only well separated on PC2. It was also evident that the wild fish had a wider dietary history, leading to higher variation in individual fatty acid compositions.

In conclusion, adipose fin and muscle biopsies are good alternatives for non-lethal sampling of Atlantic salmon in the process of fatty acid profiling. The minimum amounts of samples to ensure sufficient material are suggested to be 0.5 to $1 \mathrm{~g}$ of adipose fin and 60 to $100 \mathrm{mg}$ of muscle. The method of storage (liquid nitrogen or dry ice) does not affect fatty acid compositions. TAG fatty acids provide the closest resemblance to dietary history. But tissues do differ in some ways, and sample series should preferably be carried out on one tissue only. TOT FAMEs supply informative data on dietary history in fatty tissues, but will differ from TAG FAMEs when total lipid levels are low; the reason for this lies in a larger contribution of phospholipid FAMEs. In wild maturing salmon, therefore, where muscle lipid is low, TOT profiling will be highly influenced by phospholipids. Data may not provide reliable information with regard to previous feeding history. For fatty acid profiling of escaped salmon previously fed commercial diets, quantifying the main vegetable/terrestrial fatty acids (18:2n-6, 18:3n-3 and 18:1n-9) is sufficient to provide reliable information to identify recently escaped farmed fish (Megdal et al. 2009, Olsen et al. 2010). Although both TOT and TAG FAMEs can be used, we argue in favour of using TAG analysis. Analysing TOT FAMEs may lead to the erroneous conclusion that the fish have switched to wild prey without this actually being the case. For example, if lean tissue is analysed, 18:2n-6 will be lowered in TOT and the level of marine PUFAs will be increased when compared to the real diets. This will not be the case for TAG. We therefore conclude that TAG has a higher accuracy compared with TOT profiling; this level of accuracy is needed in detailed studies on fish of different origins, for example when monitoring the escape histories of farmed fish that may have 
switched to natural prey. For estimating a wider range of dietary histories, like variations in wild prey preference, multivariate methods are required (e.g. PCA analysis).

Most tissues can be used for TAG fatty acid profiling. We initially examined skin mucus as an alternative non-lethal sampling (data not shown). However, mucus is low in lipids, and sampling may damage skin or scales. In cases of lethal sampling, we also tested livers, roe, peritoneal fat and tongue (data not shown). Livers will change composition postprandially and are not recommended in starved fish. Lipidrich tissues such as peritoneal fat and tongue are well suited.

Acknowledgements. Grethe Thorsheim at IMR, Matre, is gratefully acknowledged for her superb analytical skills and enthusiastic attitude towards the project. The Norwegian Ministry of Fisheries and Coastal Affairs and the Institute of Marine Research in Bergen, Norway, provided financial support for the study.

\section{LITERATURE CITED}

Abrantes KG, Lyle JM, Nichols PD, Semmens JM (2011) Do exotic salmonids feed on native fauna after escaping from aquaculture cages in Tasmania, Australia? Can J Fish Aquat Sci 68:1539-1551

Aksnes A, Gjerde B, Roald SO (1986) Biological, chemical and organoleptic changes during maturation of farmed Atlantic salmon, Salmo salar. Aquaculture 53:7-20

> Axelson DE, Standal IB, Martinez I, Aursand M (2009) Classification of wild and farmed salmon using Bayesian belief networks and gas chromatography-derived fatty acid distributions. J Agric Food Chem 57:7634-7639

Baarøy V, Gjerde B, Heggberget TG, Jensen PE and others (2004) Identifisering av rømt oppdrettslaks. Utredning fra utvalg nedsatt av Fiskeridirektøren (Identification of escaped farmed salmon. Report from Committee to the Directory of Fisheries). Fiskeridirektoratet, Bergen (in Norwegian)

Bell JG, McEvoy LA, Tocher DR, McGhee F, Campbell PJ, Sargent JR (2001) Replacement of fish oil with rapeseed oil in diets of Atlantic salmon (Salmo salar) affects tissue lipid compositions and hepatocyte fatty acid metabolism. J Nutr 131:1535-1543

Christie WW (1982) The preparation of derivatives of lipids. In: Christie WW (ed) Lipid analysis. Isolation, separation, identification and structural analysis of lipids, 2nd edn. Pergamon Press, Oxford, p 51-62

> Clifford SL, McGinnity P, Ferguson A (1998) Genetic changes in Atlantic salmon (Salmo salar) populations of northwest Irish rivers resulting from escapes of adult farm salmon. Can J Fish Aquat Sci 55:358-363

Corraze G, Kaushik S (1999) Lipids from marine and freshwater fish. Oleag Corps Gras Lipid 6:111-115

> Crozier WW (1993) Evidence of genetic interaction between escaped farmed salmon and wild Atlantic salmon (Salmo salar L.) in a Northern Irish river. Aquaculture 113:19-29

Falk-Petersen S, Mayzaud P, Kattner G, Sargent J (2009)
Lipids and life strategy of Arctic Calanus. Mar Biol Res 5: 18-39

Fernandez-Jover D, Jimenez JAL, Sanchez-Jerez P, BayleSempere J, Casalduero FG, Lopez FJM, Dempster T (2007) Changes in body condition and fatty acid composition of wild Mediterranean horse mackerel (Trachurus mediterraneus Steindachner, 1868) associated to sea cage fish farms. Mar Environ Res 63:1-18

> Fleming IA, Lamberg A, Jonsson B (1997) Effects of early experience on the reproductive performance of Atlantic salmon. Behav Ecol 8:470-480

Folch J, Lees M, Stanley HS (1957) A simple method for the isolation and purification of total lipids from animal tissues. J Biol Chem 226:497-509

> Glover KA (2010) Forensic identification of fish farm escapees: the Norwegian experience. Aquacult Environ Interact 1:1-10

- Glover KA, Skilbrei OT, Skaala O (2008) Genetic assignment identifies farm of origin for Atlantic salmon Salmo salar escapees in a Norwegian fjord. ICES J Mar Sci 65: 912-920

- Glover KA, Pertoldi C, Besnier F, Wennevik V, Kent M, Skaala $\varnothing$ (2013) Atlantic salmon populations invaded by farmed escapees: quantifying genetic introgression with a Bayesian approach and SNPs. BMC Genet 14:74

> Grahl-Nielsen O, Glover KA (2010) Fatty acids in fish scales. Mar Biol 157:1567-1576

Hand DM, Brignon WR, Olson DE, Rivera J (2010) Comparing two methods used to mark juvenile chinook salmon: automated and manual marking. N Am J Aquacult 72: $10-17$

> Henderson RJ, Tocher DR (1987) The lipid composition and biochemistry of freshwater fish. Prog Lipid Res 26:281-347

Heuch PA, Mo TA (2001) A model of salmon louse production in Norway: effects of increasing salmon production and public management measures. Dis Aquat Org 45: $145-152$

$>$ Jensen $\varnothing$, Dempster T, Thorstad EB, Uglem I, Fredheim A (2010) Escapes of fishes from Norwegian sea-cage aquaculture: causes, consequences and prevention. Aquacult Environ Interact 1:71-83

Kadri S, Mitchell DF, Metcalfe NB, Huntingford FA, Thorpe JE (1996) Differential patterns of feeding and resource accumulation in maturing and immature Atlantic salmon, Salmo salar. Aquaculture 142:245-257

Karlsson S, Moen T, Lien S, Glover KA, Hindar K (2011) Generic genetic differences between farmed and wild Atlantic salmon identified from a 7K SNP-chip. Mol Ecol Resour 11:247-253

> Megdal PA, Craft NA, Handelman GJ (2009) A simplified method to distinguish farmed (Salmo salar) from wild salmon: fatty acid ratios versus astaxanthin chiral isomers. Lipids 44:569-576

Molkentin J, Meisel H, Lehmann I, Rehbein H (2007) Identification of organically farmed Atlantic salmon by analysis of stable isotopes and fatty acids. Eur Food Res Technol 224:535-543

> Olsen RE, Henderson RJ (1989) The rapid analysis of neutral and polar marine lipids using double-development HPTLC and scanning densitometry. J Exp Mar Biol Ecol 129:189-197

Olsen RE, Skilbrei OT (2010) Feeding preference of recaptured Atlantic salmon Salmo salar following simulated escape from fish pens during autumn. Aquacult Environ Interact 1:167-174 
Olsen RE, Henderson RJ, Ringø E (1991) Lipids of Arctic charr, Salvelinus alpinus (L.). 1. Dietary induced changes in lipid class and fatty acid composition. Fish Physiol Biochem 9:151-164

Olsen RE, Dragnes BT, Myklebust R, Ringø E (2003) Effect of soybean oil and soybean lecithin on intestinal lipid composition and lipid droplet accumulation of rainbow trout, Oncorhynchus mykiss Walbaum. Fish Physiol Biochem 29:181-192

Olsen RE, Henderson RJ, Sountama J, Hemre GI, Ringø E, Melle W, Tocher DR (2004) Atlantic salmon, Salmo salar, utilizes wax ester-rich oil from Calanus finmarchicus effectively. Aquaculture 240:433-449

Olsen RE, Waagbø R, Ringø E, Lall S (2010) Alternative marine lipid resources. In: Turchini GM, Ng WK, Tocher DR (eds) Fish oil replacement and alternative lipid sources in aquaculture feeds. Taylor \& Francis, CRC Press, Boca Raton, FL, p 267-324

Sægrov H, Hindar K, Kålås S, Lura H (1997) Escaped farmed Atlantic salmon replace the original salmon stock in the River Vosso, western Norway. ICES J Mar Sci 54: 1166-1172

Schlechtriem C, Bron JE, Tocher DR (2007) Inter-individual variation in total fatty acid composition of flesh of Atlantic salmon smolts-fed diets containing fish oil or

Editorial responsibility: Kenneth Black, Oban, UK vegetable oil. Aquacult Res 38:1045-1055

Skilbrei OT (2010a) Reduced migratory performance of farmed Atlantic salmon post-smolts from a simulated escape during autumn. Aquacult Environ Interact 1: $117-125$

Skilbrei OT (2010b) Adult recaptures of farmed Atlantic salmon post-smolts allowed to escape during summer. Aquacult Environ Interact 1:147-153

Skilbrei OT, Wennevik V (2006) The use of catch statistics to monitor the abundance of escaped farmed Atlantic salmon and rainbow trout in the sea. ICES J Mar Sci 63: $1190-1200$

Skilbrei OT, Holst JC, Asplin L, Mortensen S (2010) Horizontal movements of simulated escaped farmed Atlantic salmon (Salmo salar) in a western Norwegian fjord. ICES J Mar Sci 67:1206-1215

Torstensen BE, Bell JG, Rosenlund G, Henderson RJ and others (2005) Tailoring of Atlantic salmon (Salmo salar L.) flesh lipid composition and sensory quality by replacing fish oil with a vegetable oil blend. J Agric Food Chem 53: 10166-10178

> Zhang Z, Glover KA, Wennevik V, Svåsand T and others (2013) Genetic analysis of Atlantic salmon captured in a netting station reveals multiple escapement events from commercial fish farms. Fish Manag Ecol 20:42-51

Submitted: March 13, 2013; Accepted: October 21, 2013

Proofs received from author(s): November 7, 2013 